\title{
Nowe ruchy społeczne jako przedmiot badań socjologicznych w ujęciu Jana Szymczyka
}

Z ainteresowanie nowymi ruchami społecznymi (dalej: NRS) stanowi wyraźnie zakreśloną część badań naukowych w ramach uprawianej przez Jana Szymczyka socjologii, w tym socjologii życia publicznego. Jego uwagę ogniskowały między innymi zagadnienia partycypacji społecznej i aktywności obywatelskiej, oddolnej samoorganizacji jednostek czy grup, kwestie znaczenia takich aktywności dla demokracji i społeczności lokalnych. Jako osobny obszar analiz ukierunkowanie na nowe ruchy społeczne można wiązać z czasem powstania w 2007 r. Katedry Socjologii Ruchów Społecznych, kierowanej przez J. Szymczyka ${ }^{1}$. Eksploracje na temat NRS poprzedzone były studiami nad socjologią Stanisława Ossowskiego, a także nad aksjologicznymi aspektami funkcjonowania państwa, systemu demokratycznego, nad usytuowaniem struktur pośrednich i organizacji społecznych. Zarysowuje się zatem w drodze naukowej J. Szymczyka kontynuacja i rozwój, zarówno w sensie pogłębiania wiedzy w obrębie rozpatrywanych zagadnień, jak i poszerzania zainteresowań o nowe wątki i obszary.

* Dr hab. Wioletta Szymczak, prof. KUL - Katedra Socjologii Kultury, Religii i Migracji, Instytut Nauk Socjologicznych, Wydział Nauk Społecznych, Katolicki Uniwersytet Lubelski Jana Pawła II, e-mail: wioletta.szymczak@kul.pl, ORCID: 0000-0002-8749-8862.

${ }^{1}$ W 2008 r. Katedra Socjologii Ruchów Społecznych została połączona z istniejącą od połowy lat 90. Katedrą Makrostruktur Społecznych, otrzymując nazwę Katedra Socjologii Makrostruktur i Ruchów Społecznych; J. Szymczyk, Katedra Socjologii Makrostruktur i Ruchów Społecznych. W stronę realizacji zasady komplementarności, w: Tradycja i wspótczesność. 90 lat socjologii w Katolickim Uniwersytecie Lubelskim, red. S. Fel, J.P. Gałkowski, J.M. Zabielska, Wydawnictwo KUL, Lublin 2009, s. 145-151. 
Socjologia ruchów społecznych była w pierwszej dekadzie XXI w. w polskiej socjologii nielicznie reprezentowana, w przeciwieństwie do socjologii światowej, w której subdyscyplina należała już do najdynamiczniej rozwijających się, na co zwracał uwagę sam J. Szymczyk. Zainteresowanie tematyką pojawiło się w polskiej socjologii wraz z powstaniem w 1980 r. „Solidarności”. Wtedy to zaczęto używać tego pojęcia na rodzimym gruncie, sięgano do koncepcji ruchów społecznych funkcjonujących na Zachodzie, wreszcie, jak pisze Sławomir Mandes, inspirowano się badaniami przyjeżdżających do Polski socjologów, politologów i historyków, którzy analizowali zjawisko "Solidarności” in statu nascendi, $\mathrm{w}$ trakcie jego dynamicznego rozwoju, stosując kategorie ruchu społecznego ${ }^{2}$. Dlatego, gdy powstały w latach 80 . inne ruchy społeczne, badania nad nimi prowadzono m.in. w nawiązaniu do fenomenu „Solidarności”, badanej z różnych perspektyw metodologicznych ${ }^{3}$. Podkreślić należy również, że zasadniczą inspiracją dla analiz ruchów społecznych stała się książka Alaina Touraine’a, Solidarność. Analiza ruchu społecznego 1980-1981, która ukazała się w marcu 1982 r., zaś w Polsce została wydana w wydawnictwie drugiego obiegu, siedem lat później, za sprawą jednego z członków zespołu badawczego. Zespół badawczy A. Touraine’a składał się z socjologów francuskich i polskich, a jego przełomowe dokonania, jak pisze Jakub Bazyli Motrenko, wpisywały się „w proces przemian metodologiczno-teoretycznych dyscypliny. Wpłynęły na sposób, w jaki ruch jest po dziś dzień konceptualizowany. Takie pojęcia jak «ruch społeczny», «ruch totalny» czy dostrzeżenie trzech nurtów w Solidarności - związkowego, demokratycznego i narodowego, z których każdy stanowił istotny komponent jego natury - na stałe weszły do sposobu ujmowania zjawisk z początku lat osiemdziesiątych w Polsce, a książka Touraine’a stanowi niezbędne odniesienie w każdej publikacji podsumowującej badania nad Solidarnością"”.

Zdając sobie sprawę z faktu, że NRS w Polsce stopniowo coraz wyraźniej i na trwałe zapisały się w krajobrazie życia publicznego, i że stanowią zarazem wyodrębniony obszar analiz socjologicznych, a jako procesy samoorganizacji są skutecznym sposobem osiągania celów i interesów grupowych ${ }^{5}$, J. Szymczyk był przekonany o konieczności i znaczeniu badań nad nimi, w czym podzielał pogląd wielu naukowców, na których też się powoływał, m.in.: Krzysztofa Gorlacha,

${ }^{2}$ S. Mandes, Ruchy społeczne w Polsce, w: Wymiary życia społecznego. Polska na przełomie XX i XXI wieku, red. M. Marody, Wydawnictwo Naukowe Scholar, Warszawa 2007, s. 439-466; https:// www.academia.edu/11945476/Ruchy_spo\%C5\%82eczne_w_Polsce, s. 9-10 (dostęp: 20.11.2021).

${ }^{3}$ Kwestie te analizuje również, uwzględniając dorobek badaczy ruchów społecznych i ich różne podejścia, J.R. Sielezin, Ewolucja NSZZ „Solidarnośćc w latach 1980-1981 jako ruchu społecznego quasi-politycznego: etapy, okresy, znamiona, w: Nowe ruchy społeczne, s. 215-231.

${ }^{4}$ J.B. Motrenko, Badanie zespołu Alaina Touraine’a nad Solidarnością. Historia i konsekwencje, „Kultura i Społeczeństwo” 2010, nr 54(4), s. 117-140.

${ }^{5}$ W. Szymczak, J. Szymczyk, Socjologia partycypacji i Nowych Ruchów Społecznych, w: 100 lat socjologii w Katolickim Uniwersytecie Lubelskim Jana Pawła II, TN KUL, Lublin 2018, s. 303-304. 
Patrica H. Monneya, Clausa Offe, Donatelli della Porty i Maria Dani, Dietera Ruchta, Radzisławy Gortat, Piotra Sztompki i innych.

W tekście najbardziej obszernym, syntetycznie i kompleksowo ujmującym zagadnienie NRS, lubelski socjolog proponuje elementy strukturalne modelu teoretycznego, który, jego zdaniem, można aplikować do badań empirycznych NRS. Wyodrębnione zagadnienia stanowią zbiór kwestii, które należałoby uwzględniać całościowo lub wybiórczo w danym przedsięwzięciu badawczym, nie ma natomiast, jak można domniemywać, przesłanek uwzględniania ich takiej, a nie innej kolejności. Odnośnie do zaplecza teoretycznego, J. Szymczyk przyznaje rację tezie, reprezentowanej m.in. przez Stevena M. Buechlera, że mówienie o teoriach NRS jest trafniejsze i bardziej adekwatne, niż o jednej teorii, jakkolwiek w ramach podejścia najbardziej ogólnego da się wskazać, wedle S. Buechlera, kilka wątków stałych, tworzących wspólny mianownik dla różnych ujęć. Znajdą się wśród nich: podkreślanie znaczenia działań symbolicznych w społeczeństwie obywatelskim, kulturowego, niezależnego od państwa czy instytucji politycznych usytuowania działalności NRS, dążenie do osiągania autonomii i suwerenności, rola wartości postmaterialistycznych, problematyzowanie kwestii budowania tożsamości zbiorowych i interesów grupowych, społeczna konstrukcja niezadowolenia i ideologii (w opozycji do ujmowania ich jako pochodzących ze strukturalnego położenia danej grupy), uznanie istnienia ukrytych i tymczasowych sieci, pozwalających na działania zbiorowe (w opozycji do tezy o tym, że odgórna organizacja jest warunkiem mobilizacji) ${ }^{6}$. Propozycja modelu badań, który mógłby być aplikowany, sytuuje się zatem w tym pierwszym ujęciu, odzwierciedlając przekonanie, że jest opcją możliwą do aplikacji, oprócz innych wariantów i koncepcji projektów empirycznych.

Punktem wyjścia i tłem dla omówienia poszczególnych elementów modelu jest w refleksji J. Szymczyka wskazanie na podstawowe przymioty ruchu społecznego oraz teleologii formułowanej przez ruchy społeczne w ogólności. W odniesieniu do NRS analiza obejmuje zagadnienia: genezy i definicji NRS, struktury organizacyjnej ruchu społecznego, koncentrycznych kręgów partycypacji i zaangażowania, osobliwości ideowo-pragmatycznych NRS (są nimi: obszary aktywności i preferowane wartości, uczestnicy, formy działań protestacyjnych), teorii i kwestii badawczych. Wymienione elementy wskazują na empiryczny rodowód modelu NRS, czyli na fakt, że stanowią one emanację procesów dokonującej się zmiany społecznej w społeczeństwach krajowych i międzynarodowych, a także te zmiany kreują, będąc korelatem przemian demokratycznych i przejawem zainteresowania obywateli zarówno swoim

${ }^{6}$ S.M. Buechler, Teorie nowych ruchów społecznych, w: Dynamika życia społecznego. Współczesne koncepcje ruchów społecznych, red. K. Gorlach, P.H. Mooney, Wydawnictwo Naukowe Scholar, Warszawa 2008, s. 162-163. 
dobrostanem, jak i udziałem w debacie publicznej, która ma służyć osiąganiu celów i realizacji interesów.

Warto zatem wskazać i przeanalizować główne wątki rozwijanej w tym obszarze tematycznym refleksji socjologicznej J. Szymczyka, z akcentem na rysy charakterystyczne jego ujęcia problematyki NRS, przywołaniem konkluzji czy propozycji, formułowanych w toku pracy badawczej, oraz zasygnalizowaniem idei i teorii, do których się odwoływał. Będzie to celem niniejszego artykułu.

\section{Ruchy społeczne w przestrzeni demokratycznej}

Zdaniem J. Szymczyka ruchy społeczne usytuowane są pomiędzy zachowaniami zbiorowymi (np. charakterystycznymi dla tłumu) a działalnością zorganizowanych i sformalizowanych struktur (np. partii politycznych) i są zazwyczaj relatywnie rozproszonymi zbiorowościami, z niskim poziomem zinstytucjonalizowania, zhierarchizowania ${ }^{7}$. Charakteryzuje je niestabilność, ulotność, kruchość. P. Sztompka oraz R. Gortat, do których nawiązuje J. Szymczyk, piszą o podwójnej morfogenezie ruchów społecznych, czyli ich wewnętrznej i zewnętrznej dynamice. Na wewnętrzną składają się fazy rozwoju, przekształceń, relacji wewnątrz struktury ruchu oraz działań skierowanych do wewnątrz: uczestników, sympatyków czy zwolenników ruchu. Morfogeneza wewnętrzna odnosi się do procesów internalizacji, apologii lub wytwarzania nowych systemów wartości, znaczeń, modelów kulturowych. Na poziomie wewnętrznym tworzą się fundamenty dla zewnętrznej działalności ruchu, dzięki powstającej na bazie podzielanych zasad, norm, wartości więzi i solidarności, spójności ruchu. Nie oznacza to jednak linearnego następstwa czasowego: ruch oddziałuje na zewnątrz od początku tworzenia się, również w trakcie procesów zachodzących wewnątrz. P. Sztompka wskazuje na cztery etapy dynamiki ruchu: powstawanie, mobilizację, rozbudowanie struktur i koniec działalności ${ }^{8}$.

Morfogeneza zewnętrzna, dostępna dla zewnętrznego obserwatora, odnosi się do relacji z podmiotami zewnętrznymi wobec ruchu, czyli np. partiami politycznymi, grupami lobbingowymi. Jak rzecz ujmuje J. Szymczyk, mowa tu o zewnętrzno-widzialnym sposobie działania ruchu, który sprowadza się do konfrontacji proponowanej przezeń wizji kultury ze strategiami jego przeciwników, konkretnych aktorów zbiorowych (instytucjonalnych i nieinstytucjonalnych). Można ją rozpoznać poprzez konkretne inicjatywy w przestrzeni publicznej, np. kampanie, manifestacje, koncerty, jednoczące ludzi wokół pewnych celów,

${ }^{7}$ P. Sztompka, Socjologia zmian społecznych, Znak, Kraków 2005, s. 256.

8 Tamże, s. 265-271 i 274; R. Gortat, O naturze nowych ruchów społecznych, w: Studia nad ruchami społecznymi, red. E. Lewicka-Banaszak, P. Marciniak, W. Modzelewski, UW, Instytut Socjologii, Warszawa 1987, s. 48. 
problemów, istotnych i nagłaśnianych przez dany ruch. Dużą rolę odgrywa w tym procesie działalność popularyzatorska, wydawnicza i medialna. Zewnętrzne oddziaływanie ruchu wzmacnia sieć społeczną, pomaga w rekrutowaniu nowych uczestników, prowadzi do redefinicji, modyfikacji dotychczasowych celów, gdy zachodzi taka potrzeba ${ }^{9}$.

Analizując ruch społeczny od strony zewnętrznej, wskazuje się na jego skuteczność we wprowadzaniu przekształceń strukturalnych, co P. Sztompka nazywa potencjałem morfogenetycznym i zwraca uwagę, że efektywność oddziaływania musi być interpretowana z uwzględnieniem rozróżnień na funkcje jawne i ukryte (nieprzewidywalne), efekty krótkoterminowe i długoterminowe, ambiwalentność i złożoność bilansu, i samej oceny skuteczności, np. w kontekście celów możliwych do osiągnięcia. Od strony zewnętrznej potencjał może ujawniać się w sposób twórczy lub destrukcyjny (gdy ruchy muszą najpierw osłabić istniejące struktury, aby potem umacniać czy rozwijać inne). P. Sztompka wyróżnia cztery typy potencjału morfogenetycznego, mianowicie: potencjał ideologiczny, czyli stopień, w jakim ruchowi udaje się rozpowszechnić preferowane idee w społeczeństwie; potencjał reformatorski, którego miarą jest zakres wprowadzenia do społeczeństwa nowych wartości, norm, stylów życia; potencjał reorganizacyjny, związany z oddziaływaniem na interakcje społeczne; potencjał redystrybucyjny, oznaczający poziom faktycznych możliwości ruchu w zakresie zwiększenia przywilejów, korzyści, gratyfikacji dla swoich członków ${ }^{10}$.

Według J. Szymczyka specyfiką Polski są obecnie inicjatywy ruchów społecznych na mniejszą skalę, a ich potencjał sprowadza się do protestów przeciw niepożądanym inwestycjom, czy też dążenia do ożywienia lokalnych tradycji. Jedne i drugie wskazują na fakt, że ludzie zmierzają do przejęcia kontroli nad swoim środowiskiem społecznym. J. Szymczyk konstatuje, nawiązując też do tez Aldony Jawłowskiej, że ,jest to w dzisiejszych czasach ważniejsza i skuteczniejsza droga prowadząca do zmiany społeczno-kulturowej niż działanie ruchów radykalnych, rewolucyjnych, stawiających sobie za cel totalną zmianę świata"’l.

Socjologowie eksplikują wielorakie znaczenie ruchów społecznych: widzą w nich przestrzeń podtrzymywania interakcji między władzą, w szczególności, a osobami wykluczonymi, zmarginalizowanymi, pozostającymi poza głównym nurtem życia społeczno-politycznego, sposób na wprowadzanie do debaty publicznej problemów tych grup. Ruchy społeczne identyfikują lub definiują,

${ }^{9}$ J. Szymczyk, Specyfika nowych ruchów społecznych, w: Wartości - interesy - struktury społeczne. Uwarunkowania ludzkiej kreatywności i partycypacji w życiu publicznym, red. J. Szymczyk, Norbertinum, Lublin 2010, s. 34-35.

${ }_{10}$ P. Sztompka, Socjologia zmian społecznych..., s. 271-273.

11 J. Szymczyk, Specyfika nowych ruchów społecznych..., s. 39 (A. Jawłowska, Rozmowa o aktualnym stanie i perspektywach rozwoju aktywności zbiorowej w Polsce [głos w dyskusji redakcyjnej], „Societas Communitas" 2007-2008, nr 2-1, s. 20). 
a czasem inspirują nowe zjawiska w życiu społecznym, Wreszcie stanowią miejsca włączania się jednostek właśnie dlatego, że ruchy społeczne mają luźne, luźno zorganizowane, a niezhierarchizowane i niezbiurokratyzowane, sformalizowane struktury $^{12}$, co dla współczesnego człowieka w płynnej ponowoczesności jest rzeczą korzystną i wygodną, bo niewymagającą deklaracji i zobowiązań. W podobny sposób widzi nowe ruchy społeczne Samuel N. Eisenstadt, traktując je jako symptom zmian w świecie współczesnym. Wyróżniają się według izraelskiego socjologa niezależnością od klasycznego modelu państwa narodowego, niezgodą na wypełnienie przydzielanych funkcji w sferze publicznej, a obecne w starych ruchach społecznych (dalej: SRS) nastawienie na podnoszenie standardu życia jest w NRS zastępowane kategoriami powiązanymi z jakością życia ${ }^{13}$. Maria Marczewska-Rytko konstatuje, że NRS są „specyficzną odpowiedzią na problemy współczesnego świata związane z globalizacją i zmianami zachodzącymi w nowoczesnych społeczeństwach oraz sposobach pojmowania rzeczywistości"14.

W analogiczny sposób rozumiał znaczenie ruchów społecznych J. Szymczyk. Rozpatrywał je w kontekście funkcjonowania społeczeństwa obywatelskiego jako wyraz poszerzania obszarów wolności i autonomii obywateli, sposób osiągania celów grupowych ${ }^{15}$. Przejawy oddolnej samoorganizacji rodzą się również tam, gdzie instytucje polityczne, demokratyczne nie nadążają za nowymi wyzwaniami i problemami społecznymi. Wówczas inicjatywę przejmują oddolne organizacje pozarządowe, a także NRS. Dlatego właśnie, twierdzi J. Szymczyk, „działalność NRS bywa postrzegana jako sposób czy medium nagłaśniania kwestii kulturowych, moralnych i stawiania ich w centrum życia społecznego. W tym sensie ruchy społeczne przyczyniają się do ożywienia nierzadko skostniałej demokracji przedstawicielskiej"16. Z powyższego wynika, że rozwój NRS można interpretować jako efekt umacniania demokracji. Mogą jednakże stanowić również odwrotny sygnał ostrzegawczy, wskazujący na nieprawidłowo funkcjonujące jej mechanizmy, skoro generują społeczny, zorganizowany oddolnie protest. Na ową ambiwalencję w interpretacji proweniencji NRS zwracają też uwagę Bert Klandermans i Sidney Tarrow w analizie kwestii mobilizacji zasobów w ruchach społecznych. Piszą o różnicy stanowisk dotyczących genezy NRS: jedni wskazują na zmianę systemu wartości z ma-

12 J. Szymczyk, Specyfika nowych ruchów społecznych..., s. 40.

13 S.N. Eisenstadt, Utopia i nowoczesność, tłum. A. Ostolski, Oficyna Naukowa, Warszawa 2009, s. 111, 312; M. Marczewska-Rytko, Nowe ruchy społeczne $w$ dobie globalizacji: uwarunkowania $i$ charakterystyka, w: Nowe ruchy społeczne, red. M. Marczewska-Rytko, D. Maj, Wydawnictwo UMCS, Lublin 2017, s. 16.

14 M. Marczewska-Rytko, Nowe ruchy społeczne..., s. 17.

15 O znaczeniu oddolnej samoorganizacji obywateli oraz struktur pośrednich i inicjatyw obywatelskich w społeczeństwach demokratycznych zob. J. Szymczyk, Pomiędzy marzeniami a faktami. Szkice socjologiczne, Norbertinum, Lublin 2005, s. 31-64.

16 J. Szymczyk, Specyfika nowych ruchów społecznych..., s. 52. 
terialnych na postmaterialistyczne, inni upatrują powstanie NRS w reakcji na państwo dobrobytu (welfare state), które generowało powstawanie nowych potrzeb i niemożliwość ich zaspokojenia w stopniu oczekiwanym, co prowadziło do współzawodnictwa, sfer deprywacji i powstawania wciąż nowych roszczeń. Jeszcze inna grupa badaczy sprowadzała okoliczności powstania NRS nie tyle do rozwoju aspiracji, ile do rosnącego napięcia społecznego związanego z industrializacją i biurokratyzacją, prowadząc nieuchronnie do zaniku tradycyjnych więzi i lojalności. Wskutek tych procesów ludzie łatwiej przyswajają wizje nowych utopii, nowych światów społecznych ${ }^{17}$.

Lubelski socjolog uważał, że badania empiryczne NRS mają istotne znaczenie dla nauk społecznych również ze względu na możliwości transponowania wiedzy pozyskanej w toku tego typu projektów na szersze obszary. Jego zdaniem poprzez analizy tej problematyki „istnieje możliwość poznania fundamentalnych mechanizmów i zjawisk kształtujących oblicze życia społecznego. Eksploracje te mogą dostarczyć wiele cennych informacji i eksplikacji w zakresie m.in. preferowanych wartości, inspirowanych i podejmowanych działań zbiorowych, aktywności społecznej, przedsięwzięć lokalno-narodowych i globalnych"18. Podobny potencjał analiz ruchów społecznych dostrzega również Sławomir Mandes, twierdząc, że analiza ruchów społecznych pokazuje, jak przebiegają procesy zmiany w społeczeństwie. „Uczestnicy ruchu społecznego wiedzą, że chcą zmienić społeczeństwo i wiedzą, jak zmiana ma wyglądać. Analizując ruchy społeczne, można więc badać, czy i na ile ludzie są w stanie zmienić bieg historii"19, co w konkluzji oznacza, że stanowią interesujący obszar badania determinant zmiany społecznej jako jednego z głównych problemów teorii socjologicznej.

\section{Cechy charakterystyczne nowych ruchów społecznych}

Analizę NRS J. Szymczyk prowadził ze świadomością istnienia nowej subdyscypliny, mającej za przedmiot problematykę ruchów społecznych, co znalazło wyraz w opracowaniu hasła encyklopedycznego Socjologia ruchów społecznych ${ }^{20}$. Powstanie NRS datuje się na lata sześćdziesiąte i siedemdziesiąte XX w. Na

17 B. Klandermans, S. Tarrow, Mobilizacja w ruchach społecznych: o syntezie koncepcji europejskich i amerykańskich, w: Dynamika życia społecznego. Współczesne koncepcje ruchów społecznych, red. K. Gorlach, P. H. Mooney, Wydawnictwo Naukowe Scholar, Warszawa 2008, s. 71.

18 J. Szymczyk, Specyfika nowych ruchów społecznych..., s. 38.

19 S. Mandes, Ruchy społeczne w Polsce, https://www.academia.edu/11945476/Ruchy_spo\%C5\%82 eczne_w_Polsce, s. 2 (dostęp: 20.11.2021).

${ }^{20}$ J. Szymczyk, Socjologia ruchów społecznych, w: Encyklopedia katolicka, t. 18, red. E. Gigilewicz, TN KUL, Lublin 2013, kol. 502-503. 
ogół przyjmuje się, że wyrastały z kontrkultury i kontestacji charakterystycznych dla tego okresu ideologii lewicowych. W tym też okresie rozpoczyna się proces instytucjonalizacji socjologii nowych ruchów społecznych jako odrębnej subdyscypliny socjologicznej ${ }^{21}$. Jej celem jest „ukazanie socjologicznych osobliwości ruchu społecznego w odróżnieniu od jego ujęcia politologicznego, historycznego, psychologicznego i kulturoznawczego"22. Pojęcia NRS używa się od tego czasu jako ogólnego, ramowego określenia dla politycznych i społecznych grup protestu, wyrosłych z ruchów studenckich lat sześćdziesiątych, zaś przymiotnik „nowe” stosuje się jako odgraniczający czasowo i jakościowo od ruchów robotniczych, kojarzonych ze starymi ruchami społecznymi. NRS nie odnoszą się w sposób wyczerpujący do żadnej konkretnej ideologii ani orientacji politycznej, co oznacza, że znajdują się wśród nich zarówno ruchy o rodowodzie konserwatywnym, jak i lewicowym ${ }^{23}$.

J. Szymczyk definiuje nowe ruchy społeczne jako „zbiór jednostek i różnych podmiotów społecznych tworzących na bazie preferowanych i aprobowanych przez nie wartości i tożsamości pewną strukturę organizacyjną, określoną sieć powiązań. Charakteryzuje się ona luźnym raczej, nieformalnym, niezbyt zhierarchizowanym ani zbiurokratyzowanym profilem oraz zróżnicowanym poziomem i stopniem partycypacji w strategiach własnego ruchu, która dostarcza mu szeroko rozumianych zasobów. Ruch dąży do propagowania lub zatrzymania, czy też powstrzymania - przy pomocy zróżnicowanych form i repertuarów działań protestacyjnych - zmian społeczno-kulturowych, ma swoich oponentów instytucjonalnych (np. agendy państwa) i nieinstytucjonalnych (np. kontrruchy)"24. W najbardziej ogólnym ujęciu zasadnicze cele NRS charakteryzuje ewolucyjność, czyli propagowanie i dążenie do stopniowego poprawiania porządku społecznego lub zmiany tylko wybranych jego elementów, w przeciwieństwie do rewolucyjnego charakteru SRS. Dlatego J. Szymczyk określa NRS jako bardziej nieformalne (oparte na luźnych więziach i komunikacji międzyludzkiej) oraz fluktuacyjne (zmienne, w zakresie struktury organizacyjnej jak i składu uczestników $)^{25}$, co koresponduje z określeniami C. Offe i Waldemara Buliry o tymczasowości, płynności i efemeryczności NRS. Te cechy dystynktywne NRS, jak je określa W. Bulira, pozwalają odróżnić NRS od innych aktorów występujących w przestrzeni publicznej w społeczeństwie ponowoczesnym. „Płynna struktura tych ruchów jest bowiem pochodną celów i zadań , jakie stawiają

21 Tamże, kol. 502-503.

22 Tamże, kol. 502.

23 R. Roth, D. Rucht, Neue Soziale Bewegungen, w: Handwörterbuch zur politischen Kultur der Bundesrepublik Deutschland, red. M. Greiffenhagen, Westdeutscher Verlag GMbH, Wisbaden 2002, s. 297.

24 J. Szymczyk, Specyfika nowych ruchów społecznych..., s. 43.

25 Tenże, Nowe ruchy społeczne i moralność, w: Leksykon socjologii moralności. Podstawy - teorie - badania - perspektywy, red. J. Mariański, Zakład Wydawniczy Nomos, Kraków 2015, s. 498. 
przed sobą ich członkowie i sympatycy”26. Wyrastają one z przekonania, że sukces nie zależy od hierarchicznej struktury, a ich cele nie znajdują się w obrębie zagadnień zdobycia czy utrzymania władzy. Siłą NRS jest ich spontaniczność umożliwiająca wolność wypowiadania i manifestowania poglądów, co wtórnie może generować powstawanie jakiejś formy samoorganizacji.

Wśród przywoływanych przez S. Buechlera autorów zróżnicowanych ujęć teorii NRS w swoich analizach zagadnienia J. Szymczyk odwołuje się m.in. do Alaina Touraina i Alberto Melucciego; rzadziej powołuje się na publikacje Manuela Castellsa, z jego koncepcjami sieciowych i miejskich NRS, czy Jurgena Habermasa lokowaniem nowych ruchów społecznych na styku systemu i świata $\dot{z} y \operatorname{cia}^{27}$. A. Touraine był rzecznikiem odróżnienia nowych ruchów społecznych od starych. Rozpatrywał je jako kategorię analityczną i rozumiał, jak pisała w 1987 r. R. Gortat, jako „nowe pole konfliktów społecznych, rozgrywających się wokół wzorców kulturowych i etycznych, które odnoszą się do całokształtu ludzkiej egzystencji. Płaszczyzną pojawienia się tych ruchów nie są relacje społeczeństwo obywatelskie - państwo, lecz samo społeczeństwo obywatelskie, w którego łonie toczy się walka o kształt reprodukcji życia społecznego"28. Tak interpretowane nie są odbiciem struktury społecznej, lecz poprzez korelację ze społeczeństwem naznaczonym procesami komputeryzacji tworzą je na drodze konfliktów.

Kryterium odróżnienia NRS od starych jest nie tyle chronologiczne, ile kulturowe, gdyż obejmuje jakość, natężenie oraz innowacyjność NRS. Zdaniem J. Szymczyka należy uwzględnić i dostrzegać fakt, że nie rezygnują one całkiem z uwzględniania historii, twórców idei, prekursorów. W kontekście zmiany kulturowej ruchy te stanowią zarówno jej przyczynę, intepretowaną wespół z innymi oddziałującymi czynnikami czy aktorami społecznymi, twórcami rozmaitych transformacji zachodzących w społeczeństwie, jak i skutek, czyli wynik wcześniejszych procesów, takich jak modernizacja, urbanizacja. Dokonując powyższych obserwacji lubelski badacz cytuje stwierdzenie D. Ruchta mówiące o tym, że „ruchy społeczne są jednocześnie wytworami i twórcami wzorów społecznych. Mimo, że działają w historycznie stworzonych i relatywnie stabilnych ramach, uczestniczą również aktywnie w zmienianiu dyskursów politycznych, układów i symboli kulturowych"29.

${ }^{26}$ W. Bulira, Nowe ruchy społeczne: nowa jakość w polityce ponowoczesnej?, w: Nowe ruchy społeczne, red. M. Marczewska-Rytko, D. Maj, Wydawnictwo UMCS, Lublin 2017, s. 31.

${ }^{27}$ S.M. Buechler, Teorie nowych ruchów społecznych..., s. 166.

${ }^{28}$ R. Gortat, O naturze nowych ruchów społecznych..., s. 40-41.

29 D. Rucht, Themes, Logics and Arenas of Social Movements. A Structural Approach, w: International Social Movement Research, t. 1, red. [red. serii], L. Kriesberg, JAI Press, Syracuse 1988, s. 306, za: J. Szymczyk, Specyfika nowych ruchów społecznych..., s. 42-43. 
Odnośnie do dyskusji na temat zasadności posługiwania się kategorią NRS, implikującą ich dającą się zidentyfikować i trafnie opisać nowość, lubelski socjolog zajmuje stanowisko, zgodnie z którym należy widzieć w nich nowych aktorów społecznych, z wyraźnie inną strukturą formalną i sposobem zorganizowania oraz specyfiką odróżniającą je od SRS. Efektem analizy funkcjonowania NRS jest teza Szymczyka, że NRS różnią się od SRS trzema przymiotami: „1. Rodzajem preferowanych wartości, areną, na której koncentruje się ich zasadnicza aktywność; 2. Bazą społeczną, z której wywodzą się ich uczestnicy; 3. Formami i repertuarami działań protestacyjnych" ${ }^{30}$. Opisując wymienione własności NRS, J. Szymczyk dowodzi ich nowości i roli kształtowania odmiennego charakteru tychże przejawów oddolnej samoorganizacji obywateli.

W analizach NRS oraz postulatach badawczych lubelski badacz zakładał istnienie „struktury organizacyjnej ruchu społecznego" (dalej, za Szymczykiem: SORS), elementu, który należy identyfikować i eksplorować empirycznie. SORS rozumie jako luźną konfederację jednostek, grup i środowisk, będącą nieformalną siecią powiązań. Tworzą ją podmioty społeczne (organizacje formalne, stowarzyszenia, wspólnoty, grupy lobbingowe, partie polityczne), utożsamiające $\mathrm{w}$ dowolnym zakresie swoje cele $\mathrm{z}$ wartościami i preferencjami ruchu i podejmujące różne działania oraz biorące udział w długotrwałej wymianie zasobów. W takim ujęciu SORS stanowi „wspólnie reagującą i działającą sieć społeczną" luźno powiązanych ze sobą grup. J. Szymczyk wyjaśnia pojęcie SORS, twierdząc, że w przypadku ruchów społecznych, kategoria „struktury” odnosi się do posiadania przezeń określonej morfogeniczności, pewnego stopnia zorganizowania i funkcjonowania w przestrzeni społecznej jako podmiot, aktor społeczny. Z kolej przymiotnik „organizacyjna” wskazuje na istnienie interakcji, więzi, identyfikacji, odróżniających ruch społeczny od tłumu ${ }^{31}$. Natomiast ze stwierdzenia, iż ruchy społeczne są sieciami wynika, że struktury organizacyjnej nie stanowi pojedyncza organizacja utożsamiająca się z wartościami danego ruchu. Co ważne, w obrębie SORS, jak podkreśla lubelski badacz, możliwe są procesy typowe zarówno dla ruchu społecznego, jak i dla organizacji formalnych, np. partii politycznych. W praktyce bywa tak, że grupy lobbingowe stanowią element strukturalny ruchu, mogą one też prowadzić działalność typową dla ruchu, posługując się strategią protestacyjną ${ }^{32}$. Warto odnotować, że zagadnienie organizacji ruchów społecznych stanowi osobny i interesujący przedmiot badań przedstawicieli nauk społecznych z uwagi na fakt, że stanowią, jak piszą Beth

${ }^{30}$ J. Szymczyk, Specyfika nowych ruchów społecznych..., s. 43, 53.

31 Tamże, s. 44, 47.

32 J. Szymczyk przyjmuje rozróżnienie D. Ruchta na trzy podstawowe modele (nieformalny, lobbingowy i partyjny) struktury organizacyjnej ruchu społecznego. Podkreśla jednakże, że w praktyce trudno je od siebie odseparować, choćby w celach analitycznych. 
Schaefer Caniglia i JoAnn Carmin, unikatowe całości i zasługują, jako takie, na szczególną uwagę ${ }^{33}$.

W empirycznym podejściu do SORS warto uwzględnić, zdaniem J. Szymczyka, zależności pomiędzy rodzajami sieci a przejawami działań zbiorowych oraz procesami mobilizacji zasobów i poddawać analizie uwarunkowania społeczno-polityczne relacji w niej zachodzących. Lubelski socjolog przywołuje i potwierdza tezy D. della Porty i M. Diani o sensowności zastosowania modelu „sieciowej organizacji” w badaniach ruchów społecznych. Jej istotą jest „łączenie elementów charakterystycznych dla struktury formalnej z elementami typowymi dla mniej sformalizowanej struktury sieciowej" ${ }^{34}$. Model proponowanej do analizy SORS „organizacji sieciowej” zakłada autonomię podmiotów, poziomy charakter integracji, elastyczność celów, wielopłaszczyznowość interakcji ${ }^{35}$.

Jedną z osi dyskusji na temat NRS jest pytanie o specyfikę ich zasadniczej orientacji i kwalifikowanie jej jako kulturowej lub politycznej. J. Szymczyk skłania się do poglądu, że NRS mają charakter bardziej socjokulturowy niż socjopolityczny, gdyż sfera kulturowa jest wyraźniej eksponowana w ich założeniach ideowych i działalności ${ }^{36}$. Nawiązuje tym samym do rozróżnienia A. Touraine’a, według którego cechą typową dla NRS jest opozycyjność wobec zinstytucjonalizowanej i konwencjonalnej polityki, a co za tym idzie, bardziej kulturowa orientacja i obszary oddziaływania. Nie bez racji J. Szymczyk konstatuje, że jednoznaczne przyjęcie tej dychotomii nie jest w pełni adekwatne w wyjaśnianiu specyfiki NRS. Arbitralne rozstrzyganie o ich politycznym lub kulturowym nachyleniu nie odpowiada obserwacjom rzeczywistości społecznej. Wszystkie ruchy społeczne wyrastają z jakichś tradycji kulturowych i preferują określone orientacje symboliczne, czyli w tym sensie są istotnie „kulturowe”. Jednocześnie bezpośrednio czy pośrednio zajmują też stanowiska polityczne, wypowiadają się na tematy społeczno-polityczne, próbują wywierać wpływ na ośrodki władzy i w tym znaczeniu są również „polityczne”, nawet jeśli dystansują się od tradycyjnego dążenia do przejęcia władzy w państwie, regionie, mieście ${ }^{37}$. J. Szymczyk przychyla się w tej kwestii do jednego z poglądów referowanych

33 Analizują oni organizację ruchów społecznych w kontekście teorii mobilizacji zasobów, z perspektywy politycznej oraz teorii kulturowych i poznawczych, pokazując, że każda z perspektyw w inny sposób podchodzi do specyfiki ruchów społecznych jako całości właśnie i inaczej umiejscawia zagadnienie znaczenia oraz rodzaju ich wewnętrznej struktury; B. Schaefer Caniglia, J. Carmin, Badania organizacji ruchów społecznych: klasyczne perspektywy i nowe trendy, w: Dynamika życia społecznego. Współczesne koncepcje ruchów społecznych, red. K. Gorlach, P.H. Mooney, Wydawnictwo Naukowe Scholar, Warszawa 2008, s. 98-110.

34 W. Ziętara, Struktury sieciowe europejskiego ruchu politycznego Zielonych, „Annales UMCS, sectio K - Politologia" 2017, t. 24, nr 2, s. 119-136.

35 J. Szymczyk, Specyfika nowych ruchów społecznych..., s. 48.

36 Tenże, Nowe ruchy społeczne i moralność..., s. 497.

37 W. Szymczak, J. Szymczyk, Socjologia partycypacji społecznej..., s. 307. 
przez S. Buechlera w ramach prezentacji stanowisk krytycznych wobec tezy o politycznym charakterze NRS. Stwierdza, że z ich działalnością mogą się łączyć także „ukryte” efekty politycznej natury (rozwój świadomości, socjalizacja polityczna, upolitycznienie procesów decyzyjnych itp. $)^{38}$.

\section{Kategorie uczestnictwa i działalność NRS}

Badanie aktywności w NRS wiąże się ze wskazaniem w SORS typów przynależności, co implikuje rozróżnienie jakości uczestnictwa. Wyróżnikiem przynależności do NRS jest najpierw, jak pisze J. Szymczyk, delimitowanie proweniencji uczestników, które oznacza przekroczenie podziału klasowego, typowego dla SRS. O dynamice i mobilizacji decydują wartości i potrzeby włączających się ludzi, nie zaś ich klasowa przynależność. Zazwyczaj wyróżnia się dwie grupy uczestników NRS: pierwsza obejmuje osoby zmarginalizowane, których dotknęła deprywacja potrzeb, powiązana niejednokrotnie $\mathrm{z}$ radykalizacją poglądów. Łączy ich ideowa identyfikacja z określonymi problemami. Drugą grupę stanowią osoby reprezentujące nową klasę średnią: często młode, wykształcone, o dobrym statusie ekonomicznym, świadome pewnych procesów i zjawisk, posiadające zasoby czasu, pieniędzy, energii, gotowości do działania, zatrudnione w administracji, oświacie, mediach, ochronie zdrowia ${ }^{39}$.

Wykorzystując pojęcie P. Sztompki, J. Szymczyk postuluje uwzględnienie w badaniach koncentrycznych kręgów partycypacji, które odpowiadają różnym formom włączania się w działalność ruchu oraz stopniowi zaangażowania. Inaczej działają bowiem stowarzyszenia czy organizacje identyfikujące się z centrum ruchu, podejmujące bezpośrednie inicjatywy na rzecz zwolenników, poprzez propagowanie praktyk symbolicznych, kulturowych czy stylów życia. Inaczej funkcjonują w ramach NRS organizacje, takie jak media, instytucje edukacyjne, wydawnictwa, kluby czy sklepy, których działania mają charakter wspomagający, ale niejako od zewnątrz. O rzeczywistym uczestnictwie w ruchu nie można też mówić na podstawie sporadycznego czy jednorazowego udziału w jakimś działaniu. Partycypacja polega tu na wielokrotnym udziale (co sprawia, że mówi się nie o członkach, ale o uczestnikach NRS) w przedsięwzięciach ruchu, i jako taką należy ją badać ${ }^{40}$.

Z perspektywy oceny jakości uczestnictwa, posługując się koncepcją koncentrycznych kręgów partycypacji, wskazuje się najpierw zdeterminowanych

\footnotetext{
${ }^{38}$ S.M. Buechler, Teorie nowych ruchów społecznych..., s. 173-174; J. Szymczyk, Nowe ruchy społeczne i moralność..., s. 496-502.

${ }^{39}$ J. Szymczyk, Specyfika nowych ruchów społecznych..., s. 59; tenże, Nowe ruchy społeczne i moralność..., s. 498.

40 Tenże, Specyfika nowych ruchów społecznych..., s. 49.
} 
do zaangażowania i znajdujących się w samym centrum ruchu przywódców, aktywistów, ideologów. Na kręgu szerszym i liczniejszym znajdą się działacze, zwolennicy, aktywni sympatycy. Na trzecim z kolei umiejscowieni są „bierni sympatycy", czyli ludzie utożsamiający się z celami i wartościami ruchu, ale nie włączający się w jego inicjatywy. Czwarty krąg tworzą bierni „pasażerowie na gapę", doceniający idee ruchu i liczący na to, że uzyskanie przezeń konkretnych celów przyniesie profity również im. Ci ostatni nie chcą podejmować ryzyk związanych z identyfikowaniem się z ruchem, liczą natomiast na ewentualne korzyści i sukcesy. Piąty krąg stanowią „kibice”, czyli publiczność ruchu, która obserwuje, ocenia jego program, ideologię, akcje, działania, protesty ${ }^{41}$. P. Sztompka osadza wymienione stopnie uczestnictwa w dwóch pierwszych etapach dynamiki ruchu (powstaniu i mobilizacji) i sposobach rekrutacji do ruchu, różnych jego członków. Na etapie powstania dokonuje się m.in. proces uwspólniania sytuacji, uświadomienia sobie przez konkretne jednostki potrzeby działania, zmiany, wyartykułowanie uogólnionego przekonania o potrzebie i możliwościach zmiany. Wśród najbardziej zaangażowanych znajdują się osoby bezpośrednio zainteresowane realizacją celów ruchu, włączone w początkowy etap mobilizacji, inspirowanych zazwyczaj jakimś wydarzeniem bądź warunkami powodującymi zaistnienie ruchu ${ }^{42}$.

W literaturze przedmiotu przyjmuje się, że typową strategią działania NRS, odróżniającą je od innych aktorów w przestrzeni publicznej, są protesty podejmowane z powodu braku innych kanałów komunikowania $\mathrm{z}$ władzą, decydentami oraz nieskuteczności innych form wywierania wpływu. Warto dodać za W. Bulirą, że NRS, jako oddolne i dobrowolne przejawy samoorganizacji, inicjują niejednokrotnie współczesną debatę publiczną, we współczesnym modelu zachodniego państwa demokratycznego stanowią wręcz motor napędzający dyskurs społeczeństw demokratycznych, tworząc też platformę dyskusji i wymiany poglądów, w szczególności dotyczących palących problemów społecznych. Jako takie przejmują zadania partii politycznych, choć nimi nie są ani też ich działanie nie lokuje się w obszarze polityki, co zresztą sygnalizuje wcześniej wzmiankowana dyskusja dotycząca ich kulturowego lub politycznego charakteru $^{43}$. Wreszcie, poprzez swoją niestabilność i ukierunkowanie na specyficzne i wąskie zagadnienia oddają charakter aktualnych nastrojów społecznych i wprowadzają je do publicznej wymiany stanowisk.

Protesty mają charakter swoistej komunikacji. Są sposobem zwracania uwagi opinii publicznej na ideologię czy cele NRS, próbą dążenia do uzyskania społecznej legitymizacji propagowanych idei. Oddziałują do wewnątrz:

${ }^{41}$ Tamże, s. 49-51.

${ }^{42}$ O kolejnych etapach i ich dynamice zob. P. Sztompka, Socjologia zmian społecznych..., s. 267-271.

${ }^{43}$ W. Bulira, Nowe ruchy społeczne: nowa jakość w polityce ponowoczesnej?..., s. 32. 
na uczestników ruchu i ich wewnętrzną solidarność, a także na zewnątrz, na różne środowiska społeczne, wraz z możliwością pozyskania ich przychylności. J. Szymczyk niuansuje te kwestie, pokazując np., że radykalne, ekstremalne, niekonwencjonalne formy protestu zazwyczaj nie wpływają na proces pozyskiwania zwolenników, a na wzrost poziomu poparcia społecznego mogą lepiej wpływać działania pokojowe. Podobnie jak inni badacze lubelski socjolog sygnalizuje zmienną czasu, zgodnie z którą stopień radykalizmu i oryginalności protestów w fazie początkowej z czasem ulega rutynizacji, formy protestu tracą na swej żywiołowości, atrakcyjności i spontaniczności, by w fazie końcowej doprowadzić do jakościowego, ale i ilościowego ograniczenia działań i spadku liczby przyciąganych zwolenników ${ }^{44}$.

Aktywność protestacyjna NRS nosi niejednokrotnie znamiona konfliktu, co uznaje się za socjologiczny wyznacznik NRS. Konflikty łączące się z działalnością NRS mają na celu przeprowadzenie zmian społecznych albo przeciwstawienie się transformacjom dokonywanym w życiu publicznym. Z tej racji, zdaniem J. Szymczyka, kategorię konfliktu (oporu, buntu, sprzeciwu, kontestacji, protestu) należy uwzględniać podczas analiz teoretycznych i badań empirycznych NRS. Zadaniem badacza jest opisanie jego genezy, przebiegu, faz, stosowanych środków, symboli oraz przyczyn zakończenia ${ }^{45}$. Konflikt sytuowany w obszarze kultury dotyczy np. „administrowania społecznymi potrzebami, ukierunkowania procesów konsumpcji, poprawy stylu czy jakości życia (np. w zakresie ochrony środowiska naturalnego, domagania się równych praw dla różnych mniejszości, równouprawnienia płci, tożsamości grupowej, autonomii jednostki)" 46 .

Opozycyjny charakter NRS zakłada wspomniany wyżej M. Castells, który stosuje pojęcie usieciowionych ruchów społecznych. Jak pisze M. Marczewska-Rytko, „według Castelsa usieciowione ruchy społeczne stanowią wielowymiarowy bunt, który wynika nie tylko z ubóstwa, kryzysu ekonomicznego czy też braku demokracji. Głównej przyczyny ich zaistnienia upatruje on w upokorzeniu wywołanym przez cynizm i arogancję rządzących. Cechy charakterystyczne tych inicjatyw to ignorowanie partii politycznych, nieufność wobec mediów, odrzucenie przywództwa, przyjęcie nieformalnej struktury organizacyjnej, odbywanie debat i uczestnictwo w procesie decyzyjnym w internecie oraz podczas lokalnych zgromadzeń" 47 .

Zdaniem J. Szymczyka uznanie, że konflikt stanowi fenomen charakterystyczny dla NRS, nie powinno przesłaniać działalności tych ruchów, które mają za cel rozwój, odnowę moralną, propagowanie alternatywnych stylów życia,

\footnotetext{
44 J. Szymczyk, Specyfika nowych ruchów społecznych..., s. 62-63.

45 W. Szymczak, J. Szymczyk, Socjologia partycypacji społecznej..., s. 307.

46 J. Szymczyk, Nowe ruchy społeczne i moralność, s. 499.

47 M. Marczewska-Rytko, Nowe ruchy społeczne..., s. 23.
} 
konsumpcji, nastawionych na pomoc (ruchy hospicyjne), czyli takich, w których czynnikiem mobilizacyjnym jest poczucie solidarności wobec jakiejś idei. Ten typ ruchów badacze określają ruchami konsensusu, a niektórzy nie zaliczają ich do kategorii ruchów społecznych ${ }^{48}$. Przyjęcie optyki, zgodnie z którą konflikt stanowi socjologiczny wyznacznik NRS, stawia pytanie o usytuowanie i zakwalifikowanie ruchów konsensusu i ruchów religijnych. J. Szymczyk skłonny jest zaliczać ruchy religijne do kategorii ruchów społecznych na podstawie uznania, że istnieje niematerialny, apersonalny adwersarz, z którym walczą, co wyczerpuje zasadnicze kryterium definicyjne, jakim jest konflikt ${ }^{49}$. Inni badacze rozpatrują te kwestie szerzej, ujmując explicite poprzez kategorię ruchów religijnych rozległy wachlarz zjawisk i ich predykatów, identyfikowanych i opisywanych poprzez szereg zmiennych, wyodrębniając też zjawisko tzw. nowych ruchów religijnych ${ }^{50}$. Takie podejście implikuje też sposób rozpatrywania specyfiki ruchów religijnych jako NRS.

Działania NRS można analitycznie podzielić według rodzajów zachowań i sposobów mobilizacji na trzy grupy, określane perspektywą liczb, perspektywą generowania szkód oraz perspektywą świadectwa. Jak pisze J. Szymczyk, odwołując się do analiz D. della Porty, w pierwszym przypadku chodzi o działania, które mają za punkt wyjścia przekonanie o sile wielości i zmierzają do zmobilizowania jak największej liczby zwolenników i uczestników inicjowanych przez ruch akcji, oddziaływanie na decydentów poprzez dane o masowości wydarzenia. Dążenia te wyrażają się np. w zbieraniu podpisów, promowaniu referendów, bombardowaniu mailami. Akcje formowane w drugiej perspektywie polegają na zamierzonym szkodzeniu przeciwnikom, co wyraża się np. w niszczeniu własności, stosowaniu przemocy, bojkotu konsumenckiego, aby spowodować spadek sprzedaży w jakiejś branży. Perspektywa trzecia polega na oddziaływaniu poprzez aktywne i czytelne dla otoczenia postawy uczestników ruchu, przemawiające poprzez silne zaangażowanie emocjonalne i stosowanie symboliki, której celem jest wpływ na sposób myślenia odbiorców, prowokowanie jego zmiany ${ }^{51}$.

W kontekście analiz specyfiki działań NRS J. Szymczyk stwierdza, że można je postrzegać jako nowy typ mediów, które komunikują ze społeczeństwem. Oznacza to, że one same są „środkami i podmiotami („nosicielami”) nowych wartości, nieraz alternatywnej wizji kultury, wywierającymi presję na polityków, opinię publiczną, świadomość społeczną, prawo, masową wyobraźnię. Ponadto zwracają uwagę na powstawanie nowych konfliktów społecznych, podczas których proponują alternatywne rozwiązania (np. alternatywne style życia,

${ }^{48}$ J. Szymczyk, Specyfika nowych ruchów społecznych..., s. 54.

49 Tenże, Nowe ruchy społeczne i moralność..., s. 499.

50 Zob. np. T. Paleczny, Nowe ruchy społeczne, Wydawnictwo Uniwersytetu Jagiellońskiego, Kraków 2010, s. 131-150.

51 J. Szymczyk, Specyfika nowych ruchów społecznych..., s. 67-70. 
alternatywną żywność)"52. J. Szymczyk porusza też zagadnienie temporalnego charakteru działania ruchów i pulsacyjności, oznaczającej cykliczność i fazowość w ich funkcjonowaniu. Kolejne etapy istnienia i działania NRS, a w nich mobilizacje, wywoływane są przez jakieś wydarzenia ważne dla danego ruchu.

W kontekście badania repertuarów działań NRS, ich umocowania w demokratycznym społeczeństwie, powstaje pytanie o zagadnienie ich skuteczności i poczucie wpływu uczestników na otaczającą rzeczywistość. Przywołane przez lubelskiego socjologa $\mathrm{w}$ ramach podsumowania poczynionych refleksji pytanie jest tym bardziej celne, że mowa o podmiotach, których działania przestały być w nowoczesnych demokracjach uważane za przejawy postaw antysystemowych; przeciwnie, stanowią trwały element demokratycznego społeczeństwa, a ich działania - akceptowalny sposób wyrażania poglądów i mobilizacji społecznej. Zgodnie z obserwacjami J. Szymczyka, w zakresie realizacji celów, skuteczność NRS jest stosunkowo mała. Natomiast docenić można wprowadzanie do debaty publicznej nowych wątków, artykułowanie problemów, uwrażliwianie opinii publicznej na postulowane kwestie, udział w zmienianiu dyskursów publicznych, układów władzy i symboli kulturowych ${ }^{53}$.

Potwierdzeniem aplikacji zarysowanych idei oraz postulatów metodologicznych lubelskiego badacza, związanych z zaproponowanym modelem badań NRS, są projekty realizowane pod jego kierunkiem, a dotyczące np.: koncepcji miejskich ruchów społecznych, ruchu obywatelskiego nieposłuszeństwa, nowego feminizmu czy ruchu konsumenckiego $0^{54}$.

\section{Aksjologiczne i moralne aspekty działalności NRS}

Charakterystyczną cechą refleksji J. Szymczyka na temat NRS są teoretyczne oraz empiryczne analizy zagadnień aksjologicznych w powiązaniu $\mathrm{z}$ aspektami moralnymi. Eksponuje on w szczególności aksjologiczne podłoże działalności w ruchach społecznych, co uwidacznia się m.in. w analizie SORS i jest wyrazem jednej z głównych perspektyw w wyjaśnianiu rzeczywistości społecznej, jaką stosował. Wydaje się też, że właśnie ta optyka - aksjologicznych fundamentów i treści działania w przestrzeni społecznej - stanie się elementem rozpozna-

52 Tamże, s. 70.

53 Tamże, s. 79, 81.

54 A. Bielecka, Cele i metody działania ruchu obywatelskiego nieposłuszeństwa. Na podstawie literatury przedmiotu, mps, Archiwum Uniwersyteckie KUL (dalej: AKUL), Lublin 2011; K. Lipińska, Pojęcie miejskich ruchów społecznych. Na podstawie literatury przedmiotu, mps, AKUL, Lublin 2015; D. Kwiatkowska, Naczelne wartości i formy działania organizacji polskiego ruchu konsumenckiego. Na podstawie literatury i stanu badań, mps, AKUL, Lublin 2009; O. Szyszka, Nowy feminizm polski w perspektywie społeczno-aksjologicznej, mps, AKUL, Lublin 2007. 
walnym jego socjologii. Potwierdzeniem są również prace dyplomowe zorientowane na ową weberowską i personalistyczną perspektywę analizy działania społecznego. Znajdują się wśród nich zagadnienia, takie jak funkcje ruchu społecznego „Solidarność” (1980-1981) z perspektywy teorii ładu aksjonormatywnego, preferowane wartości działaczy podziemnej „Solidarności” czy dominujące wartości i formy działania organizacji polskiego ruchu ekologicznego ${ }^{55}$. W realizowanych pod kierunkiem J. Szymczyka projektach badawczych często aplikowano model orientacji wartościujących, w celu zbadania aksjologicznego spektrum aspektów danego działania w przestrzeni publicznej.

Optyka aksjologiczna $w$ badaniach NRS, podobnie jak w innych obszarach naukowych eksploracji tego badacza, znajdowała miejsce uprzywilejowane ${ }^{56}$. Warto wspomnieć socjologiczne teksty poświęcone relacji pomiędzy wartościami a zachowaniami i działaniami społecznymi czy też aksjologicznym aspektom funkcjonowania struktur pośrednich w państwie i demokracji partycypacyjno-deliberatywnej ${ }^{57}$, w obrębie których sytuują się konkretyzacje dotyczące NRS. Wykorzystywane w badaniach podejście aksjologiczne pozwalało mu stwierdzić, że wartości, a konkretnie, ich „deklarowanie, a zwłaszcza uznawanie i internalizowanie - przesądzają o tym, czy ktoś znajdzie się lub nie w danym SORS-ie. Patrząc jednak z innej strony, afirmowane przez jednostki wartości mogą wiele wyjaśniać, ale wcale nie muszą się automatycznie przekładać na ich zaangażowanie, partycypację czy chęć podjęcia konkretnych działań. Nie ma prostej zależności między poparciem dla jakichś działań zbiorowych - z perspektywy określonych wartości - a decyzją o wzięciu w nich udziału. Ta ostatnia zależy bowiem od wielu innych jeszcze czynników, uwarunkowań, np. od oceny istniejących możliwości (okoliczności sprzyjających) i ograniczeń" ${ }^{58}$.

Z aksjologicznym wymiarem działalności NRS wiąże się profil moralny, który J. Szymczyk wydobywa i omawia, głównie w opracowaniu Nowe ruchy społeczne i moralność. Jego zdaniem mamy z nim do czynienia wówczas, gdy przedmiotem zainteresowania NRS „są zagadnienia będące wcześniej domeną życia prywatnego, nawet intymnego, jak np. sprawy płci, mniejszości seksualnych, zdrowia, regulacji urodzeń" ${ }^{59}$. Moralne implikacje posiada

55 M. Bobrek, Preferowane wartości działaczy podziemnej „Solidarności”. Na podstawie wybranych tekstów autobiograficznych, mps, AKUL, Lublin 2009; M. Biernat, Dominujące wartości i formy działania organizacji polskiego ruchu ekologicznego. Na podstawie literatury i stanu badań, mps, AKUL, Lublin 2009.

${ }^{56}$ Niektóre wątki były już powyżej omówione, dlatego w tej części zostaną dla jasności wywodu tylko zasygnalizowane.

57 J. Szymczyk, Wartości a zachowania i działania społeczne, w: Segmenty aktywności społecznej a wartości. Idee a praktyka, red. J. Szymczyk, Wydawnictwo KUL, Lublin 2012, s. 9-35; tenże, Odkrywanie wartości. Z problematyki socjologiczno-aksjologicznej, Polihymnia, Lublin 2004, s. $203-225$.

58 W. Szymczak, J. Szymczyk, Socjologia partycypacji społecznej..., s. 308-309.

59 J. Szymczyk, Nowe ruchy społeczne i moralność..., s. 497. 
wybór określonych wartości i celów. Założenia programowe i działania niektórych NRS mogą być bowiem formułowane z jednej strony wokół celów i wartości uniwersalnych, ponadgrupowych, $z$ drugiej zaś charakteryzuje je wąski partykularyzm grupowy oznaczający, że domagają się zaakceptowania przez ogół społeczeństwa własnej odrębności, np. „odmienności” rozmaitych grup wiekowych, płciowych, religijnych (i preferowanych przez nie wartości) jako podmiotów przynależących do SORS ${ }^{60}$. Według J. Szymczyka nie sposób zrozumieć specyfiki NRS bez wartości postmaterialistycznych, które łączą się z zagadnieniami sensu życia, godności jednostki, równowagi między człowiekiem a środowiskiem (ochroną środowiska), poczucia wspólnotowości czy autonomii, potrzeby autoekspresji, wolności słowa, demokracji bezpośredniej, tożsamości grupowej, emancypacji kobiet, zapewnienia praw rozmaitym mniejszościom i grupom wyzyskiwanym itp ${ }^{61}$. Badacz zauważa też, że mimo dominacji wartości postmaterialistycznych da się w niektórych NRS rozpoznać odniesienia do wartości materialistycznych, typowych dla SRS. Obydwie orientacje często współistnieją ze sobą, trudno jednoznacznie wskazać według lubelskiego badacza tę zasadniczą dla danego ruchu ${ }^{62}$.

Moralny wymiar J. Szymczyk dostrzega również we wspominanym obszarze charakteru uczestnictwa, które w tym typie oddolnej samoorganizacji nie limituje przynależności z powodu przynależności klasowej, czyniąc ruchy otwartymi dla zwolenników, sympatyków propagowanych idei czy ideologii. Rys moralny wiąże się też z rodzajem definiowanych celów: negatywnych, gdy mają się sprowadzać do kwestionowania istniejącego porządku i regulacji instytucjonalnych, czy pozytywnych, gdy aktywność zmierza do promocji i wprowadzania nowych rozwiązań, pozyskania dlań zwolenników. Moralny wymiar uwidacznia się również w sposobie manifestowania poglądów i mobilizowania opinii publicznej. Niepodzielny charakter żądań, eliminacja kompromisów i ustępstw w punkcje wyjścia, zamknięcie na negocjacje utrudniają prowadzenie dialogu. Wreszcie moralnym rysem naznaczone są opisane wcześniej typy działań, w szczególności perspektywa szkód $\mathrm{z}$ wpisaną weń strategią niszczenia mienia przeciwników czy stosowania przemocy, a także perspektywa dawania świadectwa, w której ideologia ruchu może nakłaniać i tak oddziaływać na uczestników, że gotowi są ryzykować bezpieczeństwo, utratę zdrowia, a nawet życia w celu demonstrowania przekonań i przesłania ruchu ${ }^{63}$.

J. Szymczyk traktuje aksjologiczne podejście jako jedno z najbardziej istotnych podejść badawczych dotyczących analiz NRS. Empiria potwierdza bowiem, że podzielane wartości często przekładają się na styl życia propagowany wewnątrz

\footnotetext{
${ }^{60}$ Tenże, Specyfika nowych ruchów społecznych..., s. $44 \mathrm{n}$.

61 Tamże, s. 56.

62 Tenże, Nowe ruchy społeczne i moralność..., s. 497.

63 Tamże, s. 497-501.
} 
ruchu i reprezentowany na zewnątrz, że NRS poprzez swoją aktywność zakotwiczoną w wybranych wartościach wytwarzają nowe tożsamości zbiorowe lub wzmacniają istniejące, kształtują postawy solidarności w ramach ruchu, wokół wartości i norm promowanych, lub solidarności w sprzeciwie wobec wartości krytykowanych czy kontestowanych ${ }^{64}$.

\section{Podsumowanie}

Badania NRS J. Szymczyka można odczytywać jako wyraz podążania za socjologiczną obserwacją dokonujących się w różnych obszarach życia społecznego zmian. Eksploracje mechanizmów funkcjonowania demokracji, znaczenia struktur pośrednich, roli oddolnej aktywności obywateli musiały prowadzić do dostrzeżenia fenomenu NRS jako wyraźnie usytuowanej i identyfikowanej formy samoorganizacji społecznej, rozwijającej się w Polsce w ostatnich dziesięcioleciach. W jakimś sensie badania te antycypowały czas obecny, cechujący się intensyfikacją aktywności oraz różnorodności NRS, potwierdzając wnikliwość i trafność jego socjologicznych obserwacji.

Analizy J. Szymczyka mają charakter syntezujący i systematyzujący kluczowe wątki refleksji z zakresu socjologii ruchów społecznych. Wraz z ich omówieniem wnoszą autorskie akcenty oraz kierują uwagę na mniej eksponowane zagadnienia, dotyczące aksjologii czy moralnego charakteru działalności NRS. O znaczeniu i oddziaływaniu tego namysłu świadczą kontynuacje i konkretyzacje w postaci studiów nad doświadczeniem konkretnych NRS, prowadzone w ramach kierowanych przez J. Szymczyka prac dyplomowych.

\section{Bibliografia}

Bielecka A., Cele i metody działania ruchu obywatelskiego nieposłuszeństwa. Na podstawie literatury przedmiotu, mps, Archiwum Uniwersyteckie KUL, Lublin 2011.

Biernat M., Dominujące wartości i formy działania organizacji polskiego ruchu ekologicznego. Na podstawie literatury i stanu badań, mps, Archiwum Uniwersyteckie KUL, Lublin 2009.

Bobrek M., Preferowane wartości działaczy podziemnej "Solidarności". Na podstawie wybranych tekstów autobiograficznych, mps, Archiwum Uniwersyteckie KUL, Lublin 2009.

Buechler S.M., Teorie nowych ruchów społecznych, w: Dynamika życia społecznego. Współczesne koncepcje ruchów społecznych, red. K. Gorlach, P.H. Mooney, Wydawnictwo Naukowe Scholar, Warszawa 2008, s. 161-188.

Bulira W., Nowe ruchy społeczne: nowa jakość w polityce ponowoczesnej?, w: Nowe ruchy społeczne, red. M. Marczewska-Rytko, D. Maj, Wydawnictwo UMCS, Lublin 2017, s. 27-35.

Eisenstadt S.N., Utopia i nowoczesność, tłum. A. Ostolski, Oficyna Naukowa, Warszawa 2009.

${ }^{64}$ Tenże, Specyfika nowych ruchów społecznych..., s. 57. 
Gortat R., O naturze nowych ruchów społecznych, w: Studia nad ruchami społecznymi, red. E. Lewicka-Banaszak, P. Marciniak, W. Modzelewski, UW, Instytut Socjologii, Warszawa 1987, s. 39-54.

Jawłowska J., Rozmowa o aktualnym stanie i perspektywach rozwoju aktywności zbiorowej w Polsce [głos w dyskusji redakcyjnej], "Societas Communitas" 2007-2008, nr 2-1, s. 11-40.

Klandermans B., Tarrow S., Mobilizacja w ruchach społecznych: o syntezie koncepcji europejskich i amerykańskich, w: Dynamika życia społecznego. Współczesne koncepcje ruchów społecznych, red. K. Gorlach, P.H. Mooney, Wydawnictwo Naukowe Scholar, Warszawa 2008, s. 64-97.

Kwiatkowska D., Naczelne wartości i formy działania organizacji polskiego ruchu konsumenckiego. Na podstawie literatury i stanu badań, mps, Archiwum Uniwersyteckie KUL, Lublin 2009.

Lipińska K., Pojęcie miejskich ruchów społecznych. Na podstawie literatury przedmiotu, mps, Archiwum Uniwersyteckie KUL, Lublin 2015.

Mandel S., Ruchy społeczne w Polsce, w: Wymiary życia społecznego. Polska na przełomie XX i XXI wieku, red. M. Marody, Wydawnictwo Naukowe Scholar, Warszawa 2007, s. 438-466; https:// www.academia.edu/11945476/Ruchy_spo\%C5\%82eczne_w_Polsce (dostęp: 20.11.2021).

Marczewska-Rytko M., Nowe ruchy społeczne w dobie globalizacji: uwarunkowania i charakterystyka, w: Nowe ruchy społeczne, red. M. Marczewska-Rytko, D. Maj, Wydawnictwo UMCS, Lublin 2017, s. 15-26.

Motrenko J.B., Badanie zespołu Alaina Touraine’a nad Solidarnościq. Historia i konsekwencje „,Kultura i Społeczeństwo" 2010, nr 54(4), s. 117-140.

Paleczny T., Nowe ruchy społeczne, Wydawnictwo Uniwersytetu Jagiellońskiego, Kraków 2010.

Roth R., Rucht D., Neue Soziale Bewegungen, w: Handwörterbuch zur politischen Kultur der Bundesrepublik Deutschland, red. M. Greiffenhagen, Westdeutscher Verlag GMbH, Wisbaden 2002, s. 296-303.

Rucht D., Themes, Logics and Arenas of Social Movements. A Structural Approach, w: International Social Movement Research, t. 1, red. [red. serii], L. Kriesberg, JAI Press, Syracuse 1988, s. 305-328.

Schaefer Caniglia B., Carmin J., Badania organizacji ruchów społecznych: klasyczne perspektywy i nowe trendy, w: Dynamika życia społecznego. Współczesne koncepcje ruchów społecznych, red. K. Gorlach, P.H. Mooney, Wydawnictwo Naukowe Scholar, Warszawa 2008, s. 98-110.

Sielezin J.R., Ewolucja NSZZ "Solidarność" w latach 1980-1981 jako ruchu społecznego quasi-politycznego: etapy, okresy, znamiona, w: Nowe ruchy społeczne, red. M. Marczewska-Rytko, D. Maj, Wydawnictwo UMCS, Lublin 2017, s. 215-231.

Sztompka P., Socjologia zmian społecznych, Znak, Kraków 2005.

Szymczak W., Szymczyk J., Socjologia partycypacji i Nowych Ruchów Społecznych, w: 100 lat socjologii w Katolickim Uniwersytecie Lubelskim Jana Pawła II, TN KUL, Lublin 2018, s. 291-315.

Szymczyk J., Katedra Socjologii Makrostruktur i Ruchów Społecznych. W stronę realizacji zasady komplementarności, w: Tradycja i współczesność. 90 lat socjologii w Katolickim Uniwersytecie Lubelskim, red. S. Fel, J.P. Gałkowski, J.M. Zabielska, Wydawnictwo KUL, Lublin 2009, s. 145-151.

Szymczyk J., Nowe ruchy społeczne i moralność, w: Leksykon socjologii moralności. Podstawy-teoriebadania - perspektywy, red. J. Mariański, Zakład Wydawniczy Nomos, Kraków 2015, s. 496-502.

Szymczyk J., Odkrywanie wartości. Z problematyki socjologiczno-aksjologicznej, Polihymnia, Lublin 2004, s. 203-225.

Szymczyk J., Pomiędzy marzeniami a faktami. Szkice socjologiczne, Norbertinum, Lublin 2005, s. 31-64.

Szymczyk J., Socjologia ruchów społecznych, w: Encyklopedia katolicka, t. 18, red. E. Gigilewicz, TN KUL, Lublin 2013, kol. 502-503.

Szymczyk J., Specyfika nowych ruchów społecznych, w: Wartości - interesy - struktury społeczne. Uwarunkowania ludzkiej kreatywności i partycypacji w życiu publicznym, red. J. Szymczyk, Norbertinum, Lublin 2010, s. 33-82.

Szymczyk J., Wartości a zachowania i działania społeczne, w: Segmenty aktywności społecznej a wartości. Idee a praktyka, red. J. Szymczyk, Wydawnictwo KUL, Lublin 2012, s. 9-35. 
Szyszka O., Nowy feminizm polski w perspektywie społeczno-aksjologicznej, mps, Archiwum Uniwersyteckie KUL, Lublin 2007.

Ziętara W., Struktury sieciowe europejskiego ruchu politycznego Zielonych, „Annales UMCS, sectio K - Politologia" 2017, t. 24, nr 2, s. 119-136.

\section{Streszczenie}

W artykule wskazano i omówiono główne wątki analiz ks. prof. Jana Szymczyka, dotyczące nowych ruchów społecznych, ich specyfiki i koncepcji badań, z akcentem na jego własne tezy i propozycje badawcze oraz cechy charakterystyczne prowadzonej refleksji socjologicznej. Zaprezentowano podejmowane przez lubelskiego socjologa zagadnienia: umiejscowienia ruchów społecznych w przestrzeni demokratycznej, specyfiki i właściwości nowych ruchów społecznych i ich teoretycznego usytuowania w socjologii, typów uczestnictwa i sposobów działania oraz aksjologicznych i moralnych aspektów funkcjonowania. Ukazano przełożenie teoretycznych zainteresowań i propozycji badawczych ks. J. Szymczyka na projekty empiryczne, realizowane pod jego kierunkiem.

Słowa kluczowe: ruchy społeczne, nowe ruchy społeczne, partycypacja społeczna, samoorganizacja obywatelska

\section{New Social Movements as a Subject Matter of Sociological Research by Rev. Prof. Jan Szymczyk}

\section{Summary}

This article discusses those main motifs in Rev. Prof. Jan Szymczyk's analyses that deal with new social movements, their specificity and a related research conception. The article puts emphasis on Szymczyk's own research claims and proposals. It also outlines those aspects of Szymczyk's oeuvre that constitute a distinctive quality of his sociological reflection. The text presents the following issues discussed by Szymczyk: the position of social movements in a democratic reality, the uniqueness and characteristic features of the new social movements and their theoretical representation in sociology, types of participation and modes of action as well as axiological and moral aspects of human and social functioning. The text explains the way in which Rev Szymczyk's theoretical interests and research endeavours led to an array of empirical projects carried out under his supervision.

Key words: social movements, new social movements, social participation, civic self-organization 